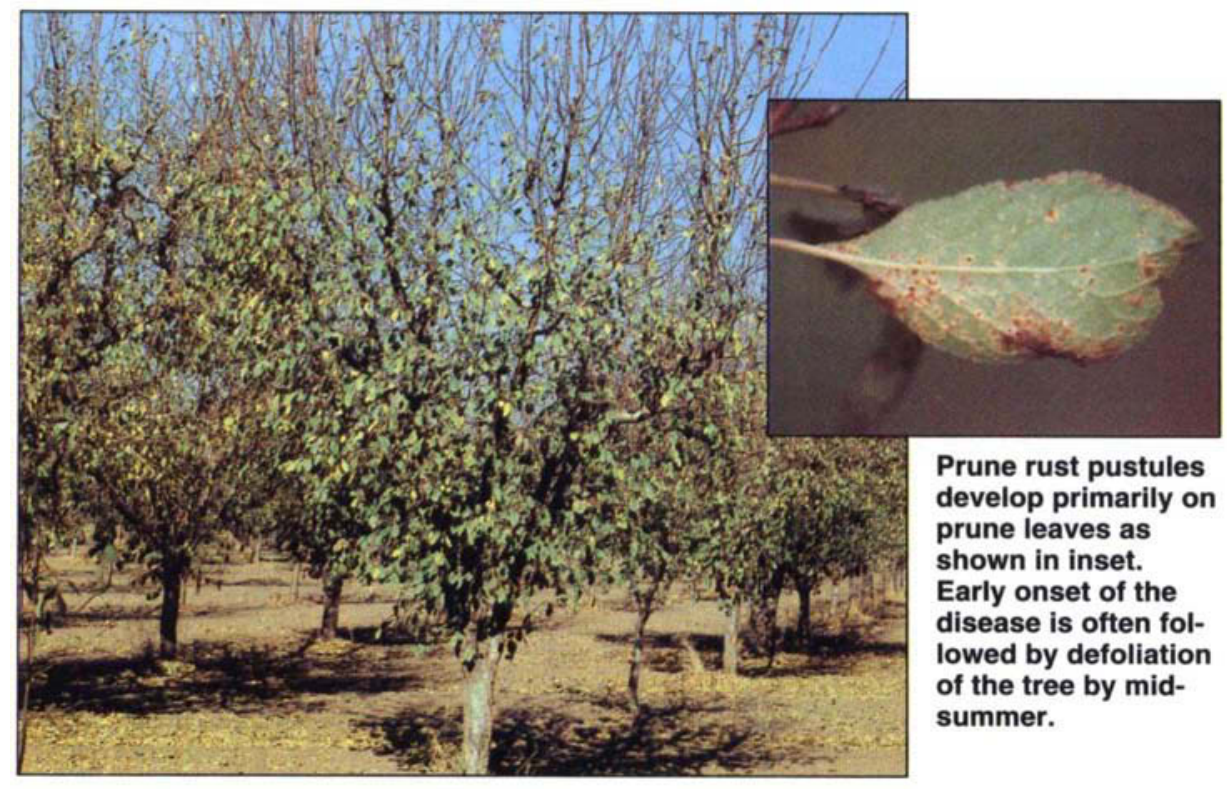

\title{
Postharvest prune rust does not lower French prune yield
}

\section{Beth L. Teviotdale G. Steven Sibbett}

\begin{abstract}
Yields and fruit quality of French prune trees in Tulare and Yuba counties were not improved by controlling late-season prune rust with mancozeb or sulfur over a 3-year period. Accelerated postharvest leaf loss induced by disease did not appear to cause a decline in yields in the following year. In a comparison of mancozeb $80 \mathrm{~W}$ and sulfur $92 \mathrm{~W}$ for control of prune rust, mancozeb provided superior control.
\end{abstract}

Outbreaks of stone fruit rust (prune rust) disease of French prune (Prunus domestica L.), caused by Tranzschelia discolor (Fuckel) Tranzschel \& Litinov, occur in many California prune orchards. Generally, the disease is more common in orchards located in the northern prune-growing districts of the Sacramento Valley than in the southern areas of the San Joaquin Valley. This reflects the greater average annual rainfall and more probable late-spring or summer rain pattern of the northern growing region. The disease is controlled by sulfur fungicides applied in late spring through summer, before symptoms appear.

Disease symptoms, prune rust pustules, are first found in late spring, if rain or high humidity prevails, and in late summer in dry years. Pustules develop on prune leaves, but rarely occur on fruit or twigs. Early onset of disease is often followed by defoliation by midsummer. Preharvest leaf infection and the accompanying excess defoliation may create difficulty in removing leaves from fruit during mechanical harvest. In dry years, defoliation induced by prune rust may not begin until after harvest.

Rust diseases are known to reduce yields of many crops including cereal grains, cotton, soybeans and coffee. Diminished yields have also been reported for stone fruit rust-infected peach and nectarine trees, and decreased yields have been associated with premature defoliation of peach trees in Florida. Preharvest defoliation from prune rust was reported to cause up to $30 \%$ reduction in long-term productivity of prune trees in New South Wales, Australia.

In California, direct damage to prune trees or fruit by prune rust has not been determined. Most California prunes are marketed as dried fruit, and factors such as preharvest defoliation that lower potential sugar content can reduce fruit size and dry weight, causing losses in yield and fruit quality. Accelerated leaf loss at or shortly after harvest over several years may compromise tree vigor and subsequent yields. The work reported here assessed the effects of prune rust on dry yield and fruit quality of French prune trees. We also compared the efficacy of mancozeb $80 \mathrm{~W}$ and sulfur $92 \mathrm{~W}$ for control of prune rust.

\section{Orchards with disease history}

We conducted experiments for 3 years in two commercial French prune orchards. One was in Tulare County, the prune-growing district in the drier southern San Joaquin Valley, and the other in Yuba County, the wetter northern area. The Tulare County orchard, planted in 1964, had a history of midsummer, preharvest prune rust outbreaks, but had never been treated to control the disease. The grower's orchard-floor management program included a permanent cover crop that apparently provided a climate favorable to the pathogen. The Yuba County orchard, planted in 1986, was clean-cultivated and had been treated annually with two applications of sulfur fungicide for prune rust control. An adjacent block of mature prune trees frequently sustained some preharvest leaf loss in spite of annual treatment. Trees in both experimental orchards were spaced 20 feet by 20 feet and were either flood or furrow irrigated.

We applied the following treatments to evaluate the impact of the disease on yield and quality and to develop some comparative efficacy data on fungicide performance: (1) mancozeb 80W, 6.0 pounds per acre; (2) sulfur $92 \mathrm{~W}, 15.0$ pounds (Tulare County) and 30.0 pounds (Yuba County), as formulated, per acre; and (3) nontreated control.

Our rates of sulfur $92 \mathrm{~W}$ represent the standard practices for the respective areas and lie within label restrictions. Mancozeb 80W, although not registered for use on prunes in Califor- 
nia, was chosen because it has been shown by others to be superior to sulfur $92 \mathrm{~W}$ for control of prune rust. All experimental materials were applied with an FMC Bean handgun sprayer operated at $150 \mathrm{psi}$. Trees were sprayed until the material was dripping off the leaves.

Each year, applications were made twice in Tulare County (late June and July of 1987, 1988 and 1989) and three times in Yuba County (early June, July and August of 1989, 1990, and 1991).

There were 40 replications, with a single tree as the experimental unit, of each treatment, arranged in a randomized complete block design. Each replicated tree received the same treatment each year. We measured fresh and dry fruit weight per tree, number of dry prunes per pound, percent soluble solids and dry ratio, and evaluated trees for disease severity.

Harvest yield was determined on August 20, 24 and 17 in 1987, 1988 and 1989 , respectively, in Tulare County, and on August 29 in 1989, 1990 and 1991 in Yuba County during the commercial harvest. In Tulare County, trees were shaken and the fruit collected on a catching frame, then transferred to a commercial harvesting bin and weighed on a fork lift fitted with an electronic load cell to determine total fresh weight. Trees in Yuba County were hand-harvested and total fresh weights measured on a portable battery-operated scale.

During each harvest, one sample of approximately 4 pounds of fresh fruit was drawn from the harvested fruit of each plot, placed in mesh bags and the fresh weight of each sample recorded. Samples were dried for 16 hours at $180^{\circ} \mathrm{F}$ in a conventional parallel flow dehydrator, then stored in open bins for 14 to 48 hours to cool and equalize the moisture content. The dried prune samples were weighed and fruit counted to determine fresh- to dryweight ratio (dry ratio) and number of dried fruit per pound (dry count). Dry count is the conventional measure of fruit quality; large fruit are desirable. An additional sample of 10 fruit was taken during harvest from each plot for soluble solids (sugar) determina-

\begin{tabular}{|c|c|c|c|c|c|c|}
\hline \multirow[b]{2}{*}{ Treatment } & \multirow{2}{*}{$\begin{array}{l}\text { Lb. as } \\
\text { formulated } \\
\text { per acre }\end{array}$} & \multicolumn{2}{|c|}{ Yield/tree* } & \multicolumn{3}{|c|}{ Fruit quality* } \\
\hline & & Fresh & Dry & $\begin{array}{c}\text { Dry } \\
\text { count/lb }\end{array}$ & $\begin{array}{l}\text { Soluble } \\
\text { solids }\end{array}$ & $\begin{array}{l}\text { Dry } \\
\text { ratio }\end{array}$ \\
\hline & & .................... & .............. & ............ & $\ldots \ldots$ & ........... \\
\hline \multicolumn{7}{|l|}{1987} \\
\hline Mancozeb 80W & 6.0 & 69.1 at & $42.0 \mathrm{a}$ & $142.5 \mathrm{a}$ & $26.4 \mathrm{a}$ & $2.8 \mathrm{a}$ \\
\hline Sulfur $92 \mathrm{~W}$ & 15.0 & $61.8 \mathrm{a}$ & $35.6 \mathrm{a}$ & $139.7 \mathrm{a}$ & $26.1 \mathrm{a}$ & $3.1 \mathrm{~b}$ \\
\hline Control & - & $59.8 \mathrm{a}$ & $34.5 \mathrm{a}$ & 143.7 a & $25.1 \mathrm{a}$ & $3.2 \mathrm{~b}$ \\
\hline \multicolumn{7}{|l|}{1988} \\
\hline Mancozeb 80W & 6.0 & $351.9 \mathrm{a}$ & $104.2 \mathrm{a}$ & $134.2 \mathrm{a}$ & $18.3 \mathrm{~b}$ & $3.4 \mathrm{a}$ \\
\hline Sulfur 92W & 15.0 & $312.8 \mathrm{a}$ & $88.6 \mathrm{a}$ & $144.9 \mathrm{a}$ & $18.1 \mathrm{~b}$ & $3.4 \mathrm{a}$ \\
\hline Control & - & $353.6 \mathrm{a}$ & $94.2 \mathrm{a}$ & $162.3 \mathrm{~b}$ & $16.8 \mathrm{a}$ & $3.6 \mathrm{a}$ \\
\hline \multicolumn{7}{|l|}{1989} \\
\hline Mancozeb 80W & 6.0 & $109.6 \mathrm{a}$ & $42.2 \mathrm{a}$ & $134.9 \mathrm{a}$ & 25.7 a & $2.7 \mathrm{a}$ \\
\hline Sulfur 92W & 15.0 & $91.4 \mathrm{a}$ & $34.8 \mathrm{a}$ & $137.1 \mathrm{a}$ & $25.7 \mathrm{a}$ & $2.6 \mathrm{a}$ \\
\hline Control & - & $88.8 \mathrm{a}$ & $34.2 \mathrm{a}$ & $138.1 \mathrm{a}$ & $26.1 \mathrm{a}$ & $2.6 \mathrm{a}$ \\
\hline
\end{tabular}

"Average of 40 single-tree replications per treatment.

†Means followed by the same letter down columns within each year do not differ according to Duncan's multiple range test, $P=0.05$.

TABLE 2. Control of prune rust in French prune trees treated for 3 consecutive years with mancozeb $80 \mathrm{~W}$ or sulfur $92 \mathrm{~W}$, Tulare County, California

\begin{tabular}{|c|c|c|c|c|c|c|c|c|}
\hline \multirow[b]{2}{*}{ Treatment } & \multirow{2}{*}{$\begin{array}{l}\text { Lb. as } \\
\text { formulated } \\
\text { per acre }\end{array}$} & \multicolumn{2}{|c|}{ Rusted leaves* } & \multicolumn{2}{|c|}{$\begin{array}{l}\text { Leaf area } \\
\text { rusted* }\end{array}$} & \multicolumn{3}{|c|}{ Defoliation ratingt } \\
\hline & & August & October & August & October & August & October & November \\
\hline & & $\ldots \ldots \ldots \ldots$ & $6 \ldots \ldots \ldots . . . . . .$. & $\ldots \ldots \ldots \ldots . .$. & .............. & & & \\
\hline \multicolumn{9}{|l|}{1987} \\
\hline Mancozeb 80W & $\begin{array}{ll}N & 6.0\end{array}$ & 0.0 & 33.6 af & 0.0 & $3.2 \mathrm{a}$ & 1.0 & $1.6 \mathrm{a}$ & $2.3 \mathrm{a}$ \\
\hline Sulfur $92 \mathrm{~W}$ & 15.0 & 0.0 & $62.5 \mathrm{~b}$ & 0.0 & $8.3 \mathrm{~b}$ & 1.0 & $1.8 \mathrm{a}$ & $2.6 \mathrm{~b}$ \\
\hline Control & - & 0.0 & $84.5 \mathrm{c}$ & 0.0 & $17.5 \mathrm{c}$ & 1.0 & $2.2 \mathrm{~b}$ & $3.2 \mathrm{c}$ \\
\hline \multicolumn{9}{|l|}{1988} \\
\hline Mancozeb 80W & $\begin{array}{l}v \\
V .0\end{array}$ & 0.0 & $19.0 \mathrm{a}$ & 0.0 & $0.8 a$ & 1.0 & $1.7 \mathrm{a}$ & - \\
\hline Sulfur $92 W$ & 15.0 & 0.0 & $59.8 \mathrm{~b}$ & 0.0 & $4.5 \mathrm{~b}$ & 1.0 & $2.0 \mathrm{~b}$ & - \\
\hline Control & - & 0.0 & $86.8 \mathrm{c}$ & 0.0 & $14.2 \mathrm{c}$ & 1.0 & $2.4 \mathrm{c}$ & - \\
\hline \multicolumn{9}{|l|}{1989} \\
\hline Mancozeb 80W & V 6.0 & 0.0 & $57.5 \mathrm{a}$ & 0.0 & $7.4 \mathrm{a}$ & 1.0 & $1.6 \mathrm{a}$ & $3.1 \mathrm{a}$ \\
\hline Sulfur $92 \mathrm{~W}$ & 15.0 & 0.0 & $94.1 \mathrm{~b}$ & 0.0 & $9.3 \mathrm{~b}$ & 1.0 & $1.7 \mathrm{a}$ & $3.4 \mathrm{~b}$ \\
\hline Control & - & 0.0 & $100.0 \mathrm{C}$ & 0.0 & $14.9 \mathrm{c}$ & 1.0 & $2.5 \mathrm{~b}$ & $4.4 \mathrm{c}$ \\
\hline
\end{tabular}

"Average of 40 single-tree replications per treatment, 50 leaves per tree.

$\dagger 1=$ no defoliation to $5=$ completely defoliated.

¥Means followed by the same letter down columns within each year do not differ according to Duncan's multiple range test, $\mathrm{P}=0.05$.

tion. Halves of the flesh from each fruit in the sample were combined and ground in a blender, and then the pulp was pressed through sections of cheesecloth. The soluble-solids content of the extracted juice was measured with a hand-held temperaturecompensated refractometer.

Leaf infection was evaluated at harvest (August) and on October 26, 3 and 18 of 1987, 1988 and 1989, respectively, in Tulare County and on October 11, 1989, and October 8, 1990, in Yuba County. We gathered 50 leaves from each tree on each date and estimated the percent of leaves with rust infections and the percent of each leaf blade with rust pustules. Defoliation was rated on these same dates, and again on November 6, 1987, and November 13, 1989, in Tulare County and November 14, 6 and 3 of 1989, 1990 and 1991, respectively, in Yuba County.

We rated leaf loss as follows: $1=$ full canopy; 2 = noticeable leaf loss and canopy slightly thinned; $3=$ noticeable leaf loss and canopy moderately thinned; $4=$ extensive defoliation with few leaves remaining; $5=$ complete defoliation with 10 or fewer leaves per tree remaining. 


\begin{tabular}{|c|c|c|c|c|c|c|}
\hline \multirow[b]{2}{*}{ Treatment } & \multirow{2}{*}{$\begin{array}{l}\text { Lb. as } \\
\text { formulated } \\
\text { per acre }\end{array}$} & \multicolumn{2}{|c|}{ Yield/tree* } & \multicolumn{3}{|c|}{ Fruit quality ${ }^{*}$} \\
\hline & & fresh & dry & $\begin{array}{c}\text { Dry } \\
\text { count/lb }\end{array}$ & $\begin{array}{l}\text { Soluble } \\
\text { solids }\end{array}$ & $\begin{array}{l}\text { Dry } \\
\text { ratio }\end{array}$ \\
\hline & & .................... & $\ldots \ldots \ldots \ldots . . . .$. & (1) & $\ldots . . . \% \ldots$ & .......... \\
\hline \multicolumn{7}{|l|}{1989} \\
\hline Mancozeb 80W & 6.0 & 71.5 at & 23.7 a & $119.6 \mathrm{a}$ & $23.3 \mathrm{a}$ & $3.1 \mathrm{a}$ \\
\hline Sulfur $92 W$ & 30.0 & $64.1 \mathrm{a}$ & 20.9 a & $120.9 \mathrm{a}$ & $22.7 \mathrm{a}$ & $3.1 \mathrm{a}$ \\
\hline Control & - & $69.8 \mathrm{a}$ & $23.5 \mathrm{a}$ & $118.4 \mathrm{a}$ & $22.7 \mathrm{a}$ & $3.1 \mathrm{a}$ \\
\hline \multicolumn{7}{|l|}{1990} \\
\hline Mancozeb 80W & 6.0 & $29.2 \mathrm{a}$ & $10.7 \mathrm{a}$ & $100.2 \mathrm{a}$ & $22.5 \mathrm{~b}$ & $2.8 \mathrm{a}$ \\
\hline Sulfur $92 \mathrm{~W}$ & 30.0 & $31.8 \mathrm{a}$ & $10.4 \mathrm{a}$ & $102.1 \mathrm{ab}$ & $21.9 \mathrm{ab}$ & $2.9 \mathrm{ab}$ \\
\hline Control & - & $48.8 \mathrm{~b}$ & $16.5 \mathrm{a}$ & $106.7 \mathrm{~b}$ & $21.4 \mathrm{a}$ & $2.9 \mathrm{~b}$ \\
\hline \multicolumn{7}{|l|}{1991} \\
\hline Mancozeb 80W & 6.0 & $113.9 \mathrm{a}$ & $34.3 \mathrm{a}$ & $95.6 \mathrm{a}$ & $22.7 \mathrm{a}$ & $3.3 \mathrm{a}$ \\
\hline Sulfur $92 \mathrm{~W}$ & 30.0 & $113.8 \mathrm{a}$ & $34.1 \mathrm{a}$ & $99.5 \mathrm{~b}$ & $23.5 \mathrm{a}$ & $3.3 \mathrm{a}$ \\
\hline Control & - & $103.1 \mathrm{a}$ & $31.8 \mathrm{a}$ & $93.5 \mathrm{a}$ & $23.4 \mathrm{a}$ & $3.2 \mathrm{a}$ \\
\hline
\end{tabular}

Average of 40 single-tree replications per treatment.

IMeans followed by the same letter down columns within each year do not differ according to Duncan's multiple range test, $P=0.05$.

TABLE 4. Control of prune rust in French prune trees treated for 3 consecutive years with mancozeb $80 \mathrm{~W}$ or sulfur $92 \mathrm{~W}$, Yuba County, California

\begin{tabular}{|c|c|c|c|c|c|c|c|c|}
\hline \multirow[b]{2}{*}{ Treatment } & \multirow{2}{*}{$\begin{array}{l}\text { Lb. as } \\
\text { formulated } \\
\text { per acre }\end{array}$} & \multicolumn{2}{|c|}{ Rusted leaves" } & \multicolumn{2}{|c|}{$\begin{array}{l}\text { Leaf area } \\
\text { rusted* }\end{array}$} & \multicolumn{3}{|c|}{ Defoliation ratingt } \\
\hline & & August & October & August & October & August & October & November \\
\hline & & ................ 9 & $6 \ldots \ldots \ldots \ldots$ & ................ & ............... & & & \\
\hline \multicolumn{9}{|l|}{1989} \\
\hline Mancozeb 80W & 6.0 & 14.2 af & $91.9 \mathrm{a}$ & $0.7 \mathrm{a}$ & $24.4 \mathrm{a}$ & 1.0 & $1.8 \mathrm{a}$ & $3.1 \mathrm{a}$ \\
\hline Sulfur 92W & 30.0 & $12.0 \mathrm{a}$ & $95.9 \mathrm{~b}$ & $0.8 \mathrm{a}$ & $29.3 \mathrm{~b}$ & 1.0 & $2.1 \mathrm{~b}$ & $3.4 \mathrm{~b}$ \\
\hline Control & - & $76.2 \mathrm{~b}$ & $100.0 \mathrm{c}$ & $14.2 \mathrm{~b}$ & $60.7 \mathrm{c}$ & 1.0 & $4.2 \mathrm{c}$ & $4.4 \mathrm{c}$ \\
\hline \multicolumn{9}{|l|}{1990} \\
\hline Mancozeb 80W & 6.0 & $0.0 \mathrm{a}$ & $7.8 \mathrm{a}$ & $0.0 \mathrm{a}$ & $0.4 \mathrm{a}$ & 1.0 & $1.2 \mathrm{a}$ & $2.2 \mathrm{a}$ \\
\hline Sulfur $92 \mathrm{~W}$ & 30.0 & $0.9 \mathrm{a}$ & $7.0 \mathrm{a}$ & $<0.1 \mathrm{a}$ & $0.4 \mathrm{a}$ & 1.0 & $1.3 \mathrm{a}$ & $2.5 \mathrm{~b}$ \\
\hline Control & - & $0.6 \mathrm{a}$ & $69.9 \mathrm{~b}$ & $0.1 \mathrm{a}$ & $16.0 \mathrm{~b}$ & 1.0 & $3.0 \mathrm{~b}$ & $4.0 \mathrm{C}$ \\
\hline \multicolumn{9}{|l|}{1991} \\
\hline Mancozeb 80W & 6.0 & $3.1 \mathrm{a}$ & - & $<0.1 \mathrm{a}$ & - & 1.0 & - & $2.6 \mathrm{a}$ \\
\hline Sulfus 92W & 30.0 & $3.8 \mathrm{a}$ & - & $0.1 \mathrm{a}$ & - & 1.0 & - & $3.1 \mathrm{~b}$ \\
\hline Control & - & $14.3 \mathrm{~b}$ & - & $0.4 \mathrm{~b}$ & - & 1.0 & - & $4.1 \mathrm{c}$ \\
\hline
\end{tabular}

-Average of 40 single-tree replications per treatment, 50 leaves per tree.

$\dagger 1.0=$ no defoliation to $5.0=$ completely defoliated.

¥Means followed by the same letter down columns within each year do not differ according to Duncan's

multiple range test, $P=0.05$.

\section{No differences in yield}

Tulare County. No significant differences were found for fresh and dry fruit weights per tree in any year, or for dry count per pound and percent soluble solids in 1987 or 1989 (table 1 ). In 1988 the dry count per pound was significantly higher and percent of soluble solids were lower in the nontreated control than in the fungicide treatments. Dry ratio was significantly lower in fruit treated with mancozeb 80W than in those treated with sulfur $92 \mathrm{~W}$ or the control in 1987, but not in 1988 or 1989 . We believe that these differences are anomalous; lower dry-ratio values were not verified by significantly higher solublesolids content. Further, the largest fruit size (low dry count) expected was not associated with lower total freshfruit weight per tree, and these differences were not repeated in our other test years.

Leaf infection and defoliation were not observed at harvest (August) in any year (table 2). By October of each year, leaf infection was significantly more severe in the nontreated control than in either fungicide treatment, and worse in trees treated with sulfur $92 \mathrm{~W}$ than in those treated with mancozeb $80 \mathrm{~W}$. Similar separation of treatments was found for defoliation ratings taken in October 1988 and November 1987 and 1989.

Yuba County. No differences occurred among treatments in any yield parameter measured in 1989 (table 3). The same was true in 1991 except for a significantly higher dry count in the sulfur $92 \mathrm{~W}$ treatment than in the mancozeb $80 \mathrm{~W}$ or control treatment. In 1990, fresh-fruit weight, but not dry-fruit weight, was significantly greater in the control than in both fungicide treatments. We attribute this to appreciable fruit drop that we think was initiated by high ambient air temperatures following the last spray application. The maximum air temperature, measured at a California Irrigation Management Information System (CIMIS) station, approximately 8 miles from the orchard, was $97^{\circ} \mathrm{F}$ on the day of treatment, and ranged from $102^{\circ}$ to $107^{\circ} \mathrm{F}$ for the next 8 days. In that year, dry count and percent soluble solids in the mancozeb $80 \mathrm{~W}$ treatment differed significantly from the nontreated control, but the sulfur $92 \mathrm{~W}$ treatment did not differ from either. Differences in these three yield parameters reflect increased fruit size and sugar content of treated fruit caused by the appreciable fruit drop.

Rust-infected leaves were present by harvest (August) each year, but defoliation had not yet begun (table 4). At that time, disease was significantly more severe in the nontreated control than in either fungicide treatment in 1989 and 1991, but not in 1990. By October 1989 , there was significantly less rust in the mancozeb $80 \mathrm{~W}$ treatment than in the sulfur $92 \mathrm{~W}$ or nontreated control treatment, and less in the sulfur $92 \mathrm{~W}$ than in the nontreated control treatment. Leaf infection in October 1990 was similar in the two fungicide treatments, and significantly less in these than in the nontreated control treatment. Defoliation was significantly less in the trees treated with mancozeb $80 \mathrm{~W}$ than in the other two treatments, and significantly less in the trees treated with sulfur $92 \mathrm{~W}$ than in the nontreated control trees by November of all 3 years. 


\section{Late rust needs no control}

Postharvest defoliation by prune rust did not adversely affect dry yield or fruit quality in the current or following seasons in our experiments. In both orchards, the significant differences among treatments were few, minor and inconsistent. Differences in postharvest defoliation among our treatments were not reflected in dissimilarities in yields the following season. If accelerated postharvest leaf loss was deleterious to the next crop, this effect was overshadowed by other horticultural factors, such as alternate bearing, and was not detected by our experiments. Although we selected orchards whose histories and locations indicated that preharvest defoliation by prune rust was likely, such leaf loss did not occur during the course of these experiments. Consequently we were not able to corroborate the yield losses attributed to preharvest defoliation by prune rust in other regions.

The history and pattern of prune rust in orchards should be considered in making treatment decision for control of this disease. Orchards with histories of early rust infection, or those situated along rivers or in high rainfall areas, should be treated annually for control of prune rust. Such orchards need protection from severe early preharvest defoliation and the associated yield losses that have been reported elsewhere. However, orchards in which rust infection and leaf loss are late-season events should not require treatment to control prune rust. Such late-season defoliation, even though repeated annually, does not appear to harm crop yield or quality.

Mancozeb (not registered for use on prunes in California) was superior to sulfur for control of prune rust.

\section{B.L. Teviotdale is Extension Plant Pa-} thologist, D.M. Harper was Staff Research Associate, and T:J. Michailides is Associate Professor, all of UC Davis, stationed at Kearney Agricultural Center, Parlier; and G.S. Sibbett is Farm Advisor, Tulare County Cooperative Extension.

The authors wish to thank the Prune Marketing Board for financial support of this research.

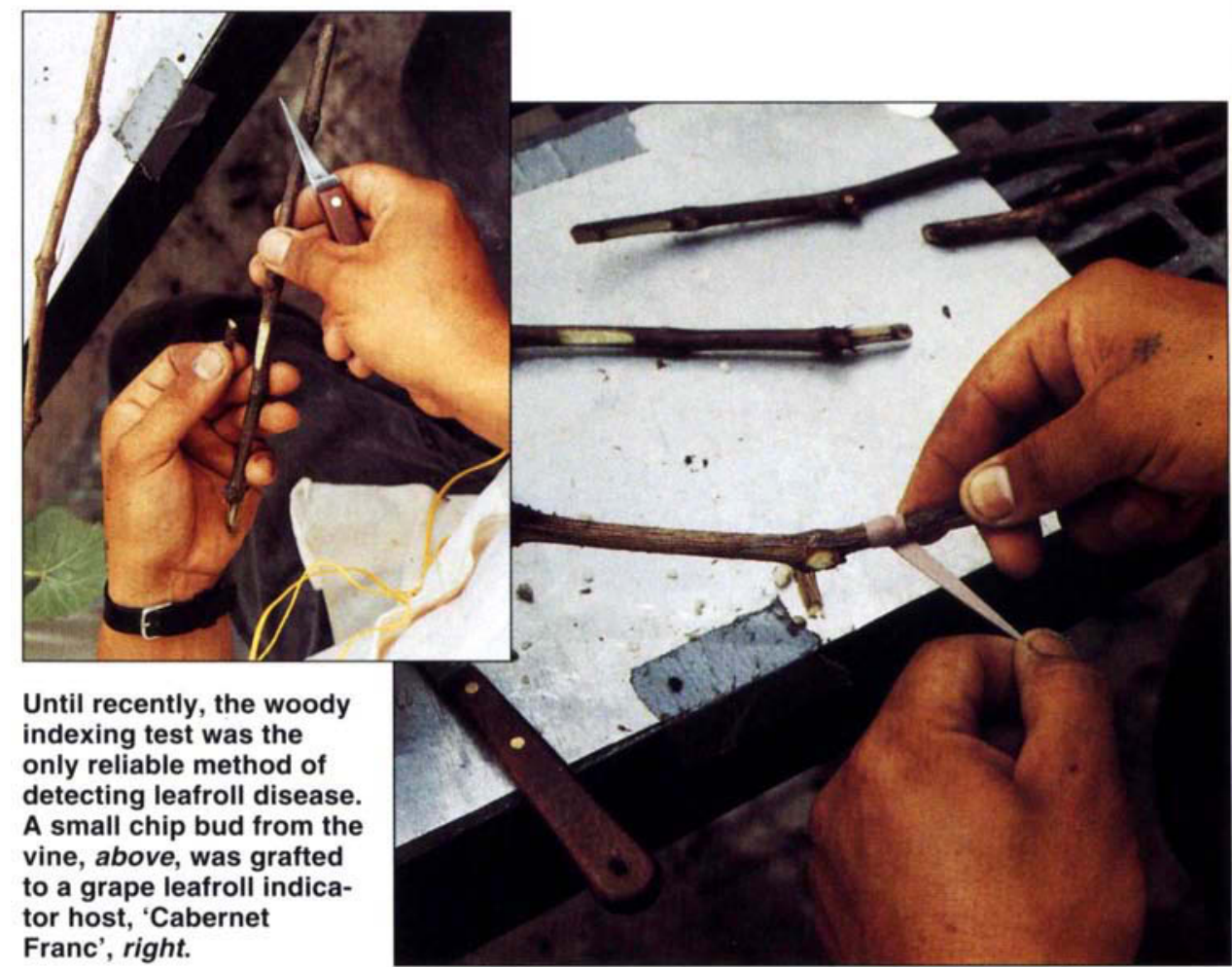

\title{
ELISA test reveals new information about leafroll disease
}

\author{
Adib Rowhani $\square \quad$ Deborah A. Golino
}

The California Grapevine Certification Program has been based on two assumptions about leafroll disease in grapevines: that the disease does not spread signiffcantly in the field in California and that the viruses that cause the disease are evenly distributed in infected vines. Careful testing of the Foundation Plant Materials Service vineyards at Davis using a new ELISA test suggests that these assumptions are not true. Changes in the California Grapevine Certification Program are underway as a result of this new information.
Virus diseases of grapevines can cause serious losses in vineyards. Because these diseases are easily spread with propagation wood when vineyards are planted, and because viruses cannot be eliminated from vineyards once plants are infected, a major virus control technique is the production of disease-tested, certified grapevines by California nurseries. This is currently done in conjunction with UC's Foundation Plant Materials Service (FPMS) and the California Department of Food and Agriculture (CDFA). Research to improve the techniques used to detect grapevine viruses has resulted in faster, more reliable tests for the certification program and in ever-higher 